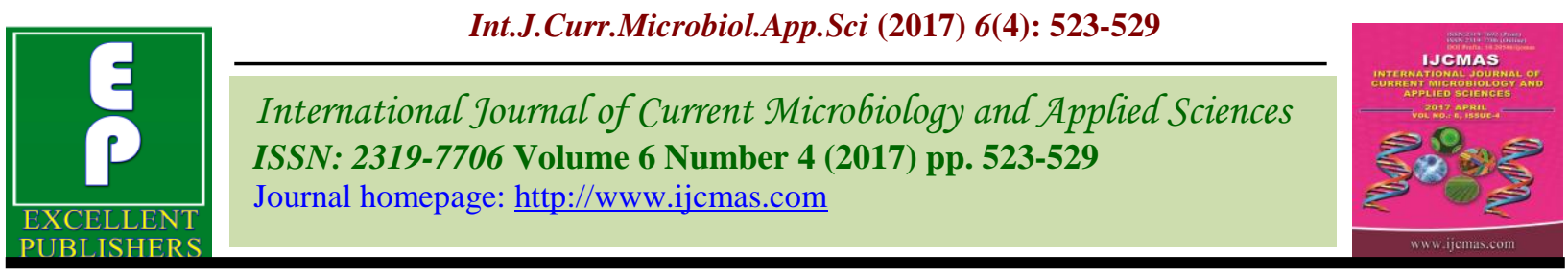

Case Study

https://doi.org/10.20546/ijcmas.2017.604.063

\title{
Urban Solid Waste Management for Sustainability: A Case Study
}

\author{
H.N. Bhange*, P.M. Ingle, B.K. Gavit and P.K. Singh \\ Department of Soil and Water Engineering, CTAE, MPUAT, Udaipur, Rajasthan, India \\ *Corresponding author
}

A B S T R A C T

Keywords

Household, Solid waste, Solid waste management, Sustainable management.

Article Info

Accepted:

06 March 2017

Available Online:

10 April 2017
Solid waste predominantly, is any garbage, refuse or rubbish which include- domestic, commercial and industrial wastes especially common for disposal. Solid waste should be handled and disposed off properly or else it poses numerous risks. The main objectives of this is to examine the types and current amount of wastes created, estimation of existing solid waste management system and finally suggested a sustainable management system of household solid waste for Nagar Panchayat area. Qualitative field data represent that about $39 \%$ households produced $2-3 \mathrm{~kg}$ waste per day and the majority percentages were organic waste (49\%). Owing to unawareness about $68 \%$ households was not segregated their waste at home. Though 54\% wastes were stored in the Nagar Panchayat dust bin, but $23 \%$ waste was thrown on the road side and $14 \%$ were anywhere. Results drawn from this research and suggested a sustainable management system will be useful for a Nagar Panchayat authority and planners, for proper management of solid waste and environmental sound city management.

\section{Introduction}

Improper handling and disposal of solid waste in open spaces poses dangers to human health as well as the environment. Waste workers and rag pickers who are involved in direct handling of solid waste are usually affected and suffer from chronic diseases. Moreover, it causes public places to appear ugly and also results in poor water, land, and air quality. Burning of heaps of waste generate greenhouse gases such as methane, carbon dioxide and nitrous oxide which could be the cause of global warming. Thus to reduce the effect of wastes on health and environment or aesthetics, Solid waste management should be undertaken. Solid Waste management is the "generation, prevention, characterization, monitoring, treatment, handling, reuse and residual disposition of solid wastes" (Waste Management, 2013). The waste management strategies developed should aim at reduction of waste generation and maximum practical benefits from the products. The waste hierarchy includes: preventing the generation of waste, reducing the generation of waste i.e. by reuse, recycling and composting. The final action is to dispose in landfills and incineration. Waste is growing by leaps and bounds in India. With a population of over 1.22 billion, rapid urbanization and modernization of India is simply inevitable. One result of a rapid urbanization, a slowly reducing gap between urban and rural, changing consumption patterns and a growing population is the problem of waste. 
Solid wastes include various types of wastes which area produced from our daily activities. In the Residential area household wastes production are depend on following factors such as, family size, behaviors and food growing season, and living style (Yousuf, 2005; Diaz et al., 1993). Urban population and mechanization have been increasing rapidly and these are creates large amount of municipal solid waste which have an adverse effect on environment, daily life of urban peoples, and other stakeholders (Alamgir et al., 2005), which is a big challenge for sustainable urban development (Chowdhury et al., 2006). The Solid waste management (SWM) is also a part of the population (Shekdar, 2009). Management of Municipal solid waste (MSW) is one of the major environmental problems and hazards to inhabitants, which is causing and creating problems to the environment (Mufeed et al., 2008). Urban solid waste management studies were carried out in Kanpur and Kolkata (Hina et al., 2008; Arun et al., 2010). SWM studies were carried out in Chennai using landfill lysimeters (Sri et al., 2009). SWM studies were carried out at Kolkata (Tumpa et al., 2009) and gave solutions to waste management problems. The study was conducted as the households rending in the Bavanagar municipal area within Kolkata metropolitan city (Ashok et al., 1991). The work evaluated on recycling of solid waste from the capital city of Delhi (Ankit et al., 2008). Recovery of solid waste in economic point of view was done in Bangalore in 1993 and 1994 (Pieter et al., 1994). The study evaluated the environmental quality and physico-chemical characteristics of the landfills at Mathkal dumping ground.

The Solid waste is responsible for our environmental degradation (fire hazards, odor nuisance, atmospheric and water pollution, aesthetic nuisance losses), health problems and economic losses. So it has become a more challenging issue for the future days. Now, sustainable Solid waste management is necessary to ensure environmental safety and sustainable development in the urban area. The main objective of this study is to examine the types and current amount of wastes generated, assessment of existing solid waste management system and finally suggested a sustainable management system of household solid waste disposal for municipal area.

\section{Materials and Methods}

\section{Study area}

Dapoli is a Nagar Panchayat in Ratnagiri district, Maharashtra, with a population of 15,713 as per census 2011. The town has an area of $21.57 \mathrm{~km}^{2}$ and acts as the main town (Taluka headquarters) for several small surrounding villages (Fig. 1).

Dapoli is famous as a hill station and is also recognized as 'Mini Mahabaleshwar'. It is $215 \mathrm{~km}$ from the state capital of Mumbai. Total 100 respondent answers were collected randomly from different wards in the Dapoli area through a defined questionnaire. Filed observation and informal discussions also conducted municipality worker, authority and others for knowing the existing management system.

\section{Awareness generation and advertising of scheme}

Realizing importance of awareness generation at household level, Nagar Panchayat carried out awareness generation activities through public announcements, displaying banners on public places, conducting ward level meetings with households lacking access to individual toilets, making presentation in schools, advertisements in newspaper etc. Nagar Panchayat called for the active members of the society and NGOs and involved them in 
activities of awareness generation. The linkage between open defecation and its ill effects were explained through these IEC activities. As understanding of the issue seeped in, the people's attitude and outlook started changing gradually, and this had an impact on their behaviour. Councilors and other staff members extended door to door awareness about the individual solid waste (Fig. 2). In this study combination methodology such survey, informal discussion and field observation were used In order to accomplish the research's objectives. Observation was done by field walk in order to know the sources of wastes generation, type and dumping sites. Photographs were taken during the observation. Informal discussions were conducted with municipality worker, authority and the inhabitants living adjacent to the dumping sites in order to know the existing waste management system and its limitation.

\section{Results and Discussion}

\section{Waste generation and types}

Municipal solid waste (MSW), also called Urban Solid Waste, and is a waste type that includes predominantly household waste (domestic waste) with sometimes the addition of commercial wastes, construction and demolition debris, sanitation residue, and waste from streets collected by a municipality within a given area. They are in either solid or semisolid form 2 and generally exclude industrial hazardous wastes. MSW can be broadly categorized into five broad categories as-

Biodegradable waste: food and kitchen waste, green waste (vegetables, flowers, leaves, fruits), paper (can also be recycled). Recyclable material: paper, glass, bottles, cans, metals, certain plastics, etc.

Inert waste: construction and demolition waste, dirt, rocks, debris. Composite wastes: waste clothing, Tetra Packs, waste plastics such as toys.

Domestic hazardous waste (also called "household hazardous waste") and toxic waste: medication, e-waste, paints, chemicals, light bulbs, fluorescent tubes, spray cans, fertilizer and pesticide containers, batteries, shoe polish.

The total quantity of solids waste generation depends on various factors such as geographic location, season of the year, population characteristics, legislation, people's attitude and it also change over time and with development, in the study area. It was found $39 \%$ and $29 \%$ household produce respectively 2-3 $\mathrm{kg}$ and 3-4 $\mathrm{kg}$ waste per day and rest of produced $1-2 \mathrm{~kg}$ (24\% households) and more than $4 \mathrm{~kg}$ (8\% households) per day (Fig. 3). The majority percentage of solid waste are originated from residential houses theses are includes food wastes, metal or non-metal waste, etc.

Study results revealed that $49 \%$ organic waste, $19 \%$ paper, $14 \%$ plastic waste, $6 \%$ Metallic, $4 \%$ glass waste, $1 \%$ wood and $7 \%$ others waste produced in the study area (Fig. $4)$.

\section{Existing system of household waste management}

In the municipal area waste collection consists of two parts, in part one household dweller collect their home produced waste, then transfer in the municipality dustbin (temporary storage place) by own willingness. Another part is done by municipality authority such as door-to-door collection and transport the waste to dustbins/containers, by tractor trolley. These solid wastes are collected for removing from the dustbins/containers and transported by open truck then these wastes are disposed in open dumping site. 
Table.1 Description of proposed sustainable waste management system

\begin{tabular}{|l|l|l|}
\hline Stage & Name of Stage & Description of Stage \\
\hline 1 & Waste generation & $\begin{array}{l}\text { These activates in which materials will be known as no longer being of value } \\
\text { and will be either thrown away or gathered together for disposal. }\end{array}$ \\
\hline 2 & $\begin{array}{l}\text { On site isolation, } \\
\text { storage } \\
\text { processing }\end{array}$ & $\begin{array}{l}\text { In this step activity will be associated with the segregation and processing of } \\
\text { solid waste at or near the point of generation. For this purpose two types of } \\
\text { storage bin will be used..... } \\
\text { I. Biodegradable waste storage bin } \\
\text { II. Non- biodegradable waste storage bin }\end{array}$ \\
\hline 3 & Collection & $\begin{array}{l}\text { In this step two types of collection method will be applied } \\
\text { I. Door-to-Door collection by municipality worker } \\
\text { II. Self-service by respective household } \\
\text { N.B.: One thing should be mind that, two types of waster will be never mixed } \\
\text { together during waste collection and bearing. }\end{array}$ \\
\hline 4 & $\begin{array}{l}\text { Storage (Temporary } \\
\text { storage of collecting } \\
\text { waste in a dustbin) }\end{array}$ & $\begin{array}{l}\text { After collection of waste, it will be stored in two separate dustbins. } \\
\text { I. Biodegradable waste storage dustbin. } \\
\text { II. Non- biodegradable waste storage dustbin. }\end{array}$ \\
\hline $\begin{array}{l}\text { Processing and } \\
\text { Recovery }\end{array}$ & $\begin{array}{l}\text { Different types of technique, equipment and facilities will be applied for } \\
\text { recovering of usable materials, conversion product. } \\
\text { This will be sold in market for processing of industrial raw material. }\end{array}$ \\
\hline 6 & Disposal & $\begin{array}{l}\text { In final step waste will be disposed on the basis of its nature } \\
\text { I. Biodegradable waste will be transferred in composting site or biogas plant } \\
\text { area. } \\
\text { II. Non- biodegradable waste will be transferred in low land areas for sanitary } \\
\text { landfilling. }\end{array}$ \\
\hline
\end{tabular}

Fig.1 Location map of study area

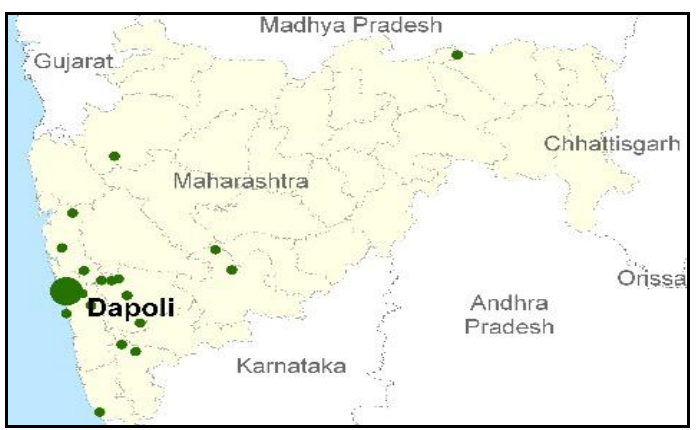

Fig.2 Awareness programme in Community level

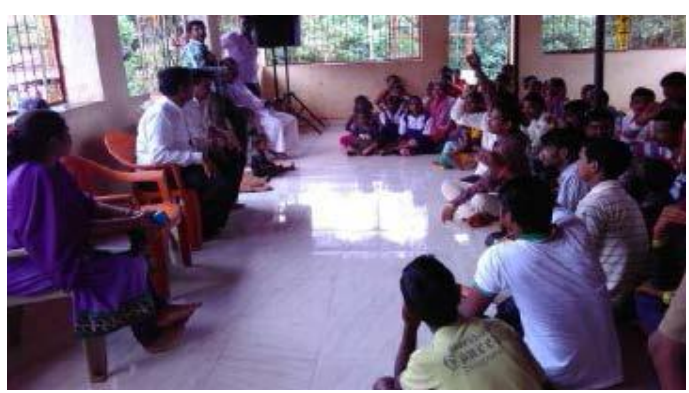

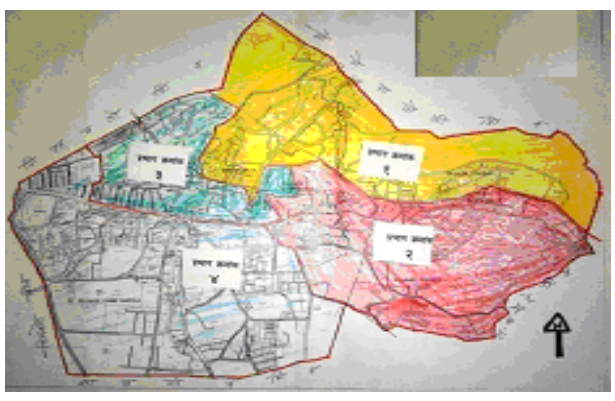

Awareness programme in a School

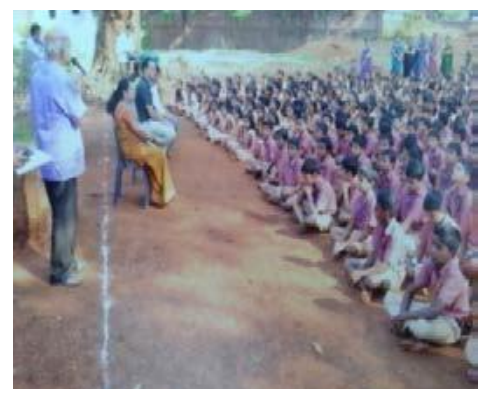


Fig.3 Abundances of Solid Wastes

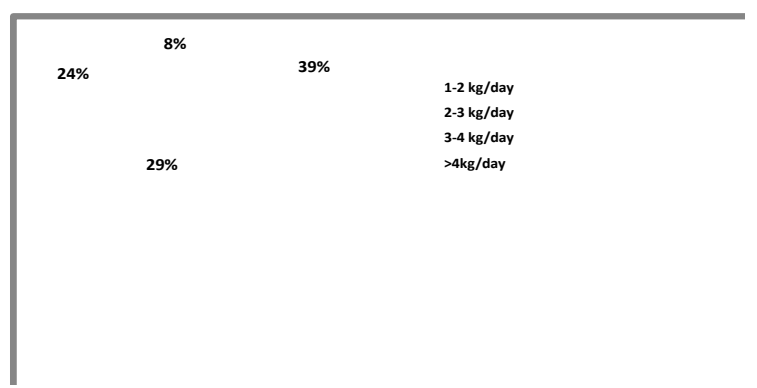

Fig.5 Solid Wastes Storage System

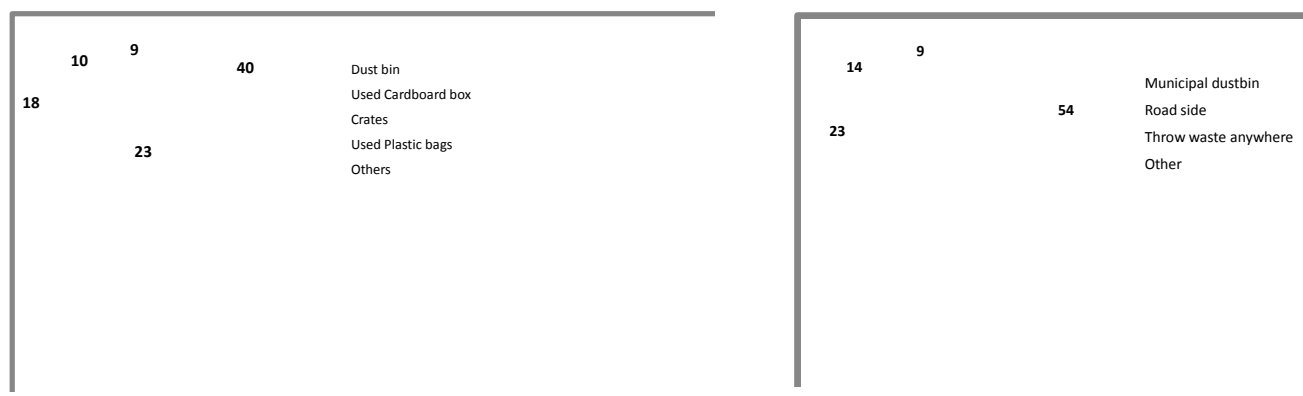

Fig.4 Household Solid Wastes

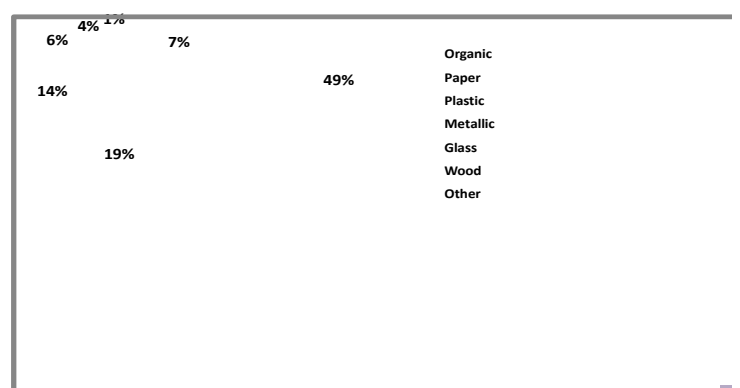

Fig.6 Solid Wastes Disposal

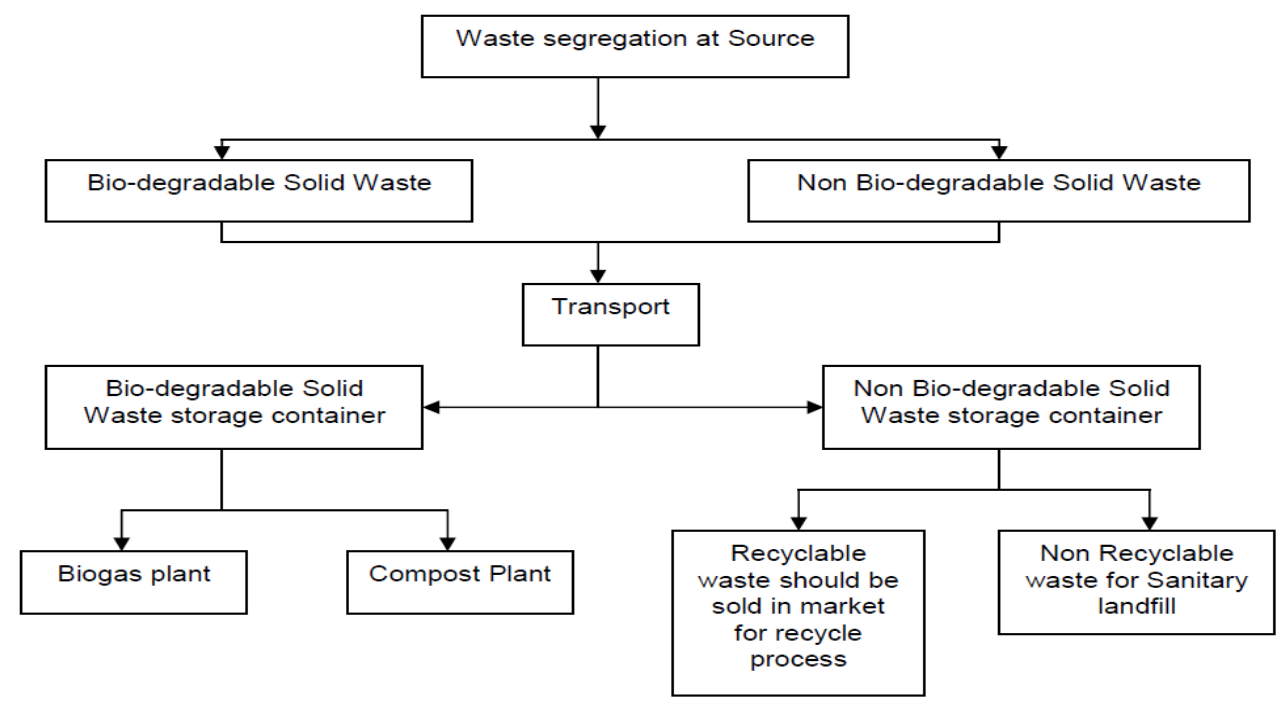

Fig. 6: Proposed sustainable Waste management system

\section{On site handling, segregation and storage}

On site handling and storage is an important element of solid waste management. On site handing defined as activities associated with the handling of solid waste until they are placed in containers for storage before collection during on site handling different types of waste are separated by the waste producer. Separation at source has obvious advantages both in terms of costs and resource recovery. In the municipal area about $68 \%$ household never segregate their household waste which not only a problem of waste management but also increase waste management cost and reduce the resource recovery rate. 
On site storage of solid waste, facilitates the collection process, collection cost and ensures the maximum collection of solid wastes generated and discourages thrown of waste indiscriminately in the streets. About $40 \%$ household used dust bin, 23\% used cardboard boxes and $18 \%$ used crates, $10 \%$ used plastic bags and 9\% others (basket, paper bags, etc.) for home produced solid waste storage at home (Fig. 5).

\section{Collection and storage of solid waste}

Collection of solid waste in urban area is very difficult and complex task. In Dapoli municipality waste are collected by two steps, in first step households (54\%) bring their garbage to the nearby public bins/containers located on the road side. Second part is municipality authorities collect waste (46\%) from door-to-door (100\%). The primary reason is that the generation of solid waste is a diffuse process that occurs in a variety of places, including individual homes, apartment buildings, etc. With the increase of the quantity of solid waste the collection task becomes even more critical because of the high cost of fuel and labour. It is estimated that $60-80 \%$ of the total cost of solid waste management is spend on the collection phase alone on the other hand municipality authority has lower budgets for waste management projects. The For temporary waste storage $54 \%$ used municipal dustbin, $23 \%$ used road side and $14 \%$ to throw waste anywhere and $9 \%$ other (Fig. 6). In case of final transformation of waste from temporary storage to disposal site municipality authority suffers various problems. Compactor trucks and farm tractor and trailer various types of vehicle are used for waste collection.

\section{Final disposal}

In urban area, for integrating solid waste system disposal site is an important factor and these sites should be safe, reliable for long-term disposal of solid wastes. Mainly low-lying lands areas are filled by urban wastes which are selected by the municipality authority. In the study area $65 \%$ waste is dumped in the lowland open space. Waste spreads all over the site during the blooming of wind its leads to soil pollution, water pollution and air pollution.

\section{Proposed sustainable waste management system}

Sustainable solid waste management system includes the generation of waste, storage, collection, transportation, processing and final disposal. This system will be Social sustainability, Environmental sustainability, Economic sustainability. The proposed waste management system also followed above criteria that are discussed in table 1. The proposed new waste management system for Dapoli municipality is present in figure 7.

It is concluded in the study area about $39 \%$ households produced 2-3 kg waste per day and majority percentages were organic waste (49\%). The present management system in the study area was not satisfactory; about $65 \%$ wastes dump in open space. This study has been developed a sustainable waste management system by considering of waste generated, the availability of resources, and the environmental conditions. It will be help for reduction of waste management cost, improvement of environmental quality, resource and energy recovery and finally will improve city living standards.

Though the level of awareness of waste collection services and waste management regulations were relatively high, the percentage of those who used other indiscriminate solid waste disposal methods like open dumping, open burning, and dumping in drainages was higher. It is essential to conduct a long-term awareness rising programme, campaigning and training programme in the area between municipality worker and residences about the sustainable waste management system and its benefit. Educational status, age, gender, cost of waste collection services and the location of residence, among others, were factors influencing solid waste management. This 
programme will be successful when municipality authority, Non-government organization and residential community will be working together, as a result they will get a clean and better city for habitant.

\section{References}

Alamgir, M., McDonald, C., Roehl, K.E. and Ahsan, A. 2005. Integrated Management and Safe Disposal of Municipal Solid Waste in Least Developed Asian Countries, Final Report of 'Waste Safe', a feasibility project under the Asia Pro Eco Programme of the EC, Department of Civil Engineering, Khulna University of Engineering and Technology, Bangladesh.

Ankit Agarwal, Ashish Singhmar, Mukul Kulshrestha and Atul K. Mittal. 2008. Municipal solid waste recycling and associated markets in Delhi, India, Resources, Conservation and Recycling, 44(1): 73-90.

Arun Kanti Biswas, Sunil Kumar, Sateesh Babu, S., Jayanta Kumar Bhattacharyya and Tapan Chakrabarti. 2010 Studies on environmental quality in and around municipal solid waste dumpsite, Resources conservation and Recycling, 55(2): 129-134.

Ashok, V., Shekdar, Krishna Swamy, K.N., Tikekar, V.G. and Bhide, A.D. 1991. Long-term planning for solid waste management in India, Waste Manage. Res., 9(6): 511-523.

Chowdhury, T., Ahmed and Syeda, A.R. 2006. Waste management in Dhaka City - A theoretical model. BRAC Univ. J., 3(2): 101-111.

Diaz, L.F., Savage, G.M. and Eggerth, L.L.
1993. Composting and recycling municipal solid waste, Cal Recovery, Inc., USA.

Hina Zia and Devadas, V. 2008. Urban solid waste management in Kanpur: Opportunities and perspectives, Habitat Int., 32(1): 58-73.

Mufeed Sharholy, Kafeel Ahmad, Gauhar Mahmood and Trivedi, R.C. 2008. Municipal solid waste management in Indian cities, A review, Waste Manage., 28(2): 459- 467.

Pieter van Beukering. 1994 An economic analysis of different types of formal and informal entrepreneurs, recovering urban solid waste, in Bangalore (India): Resources, Conservation and Recycling, 12(3-4): 229-252.

Shekdar, A.V. 2009. Sustainable solid waste management an integrated approach for Asian countries, Waste Management, 29(4): 1438-1448.

Sri Shalini, S., Obuli, P, Karthikeyan and Kurian Joseph. 2009. Biological stability of municipal solid waste from simulated landfills under tropical environment, Biores. Technol., 101(3): 845-852.

Tumpa Hazra and Sudha Goel. 2009. Solid waste management in Kolkata, India, practices and challenges, Waste Manage., 29(1): 470-478.

Waste Management. 2013. Retrieved from http://www.sciencedirect.com/science/arti cle /pii/ S0956053 X14000269 "Editorial Board/Aims and Scopes".

Yousuf, T.B. 2005. Sustainability and replication of community-based composting-a case study of Bangladesh, $\mathrm{PhD}$ Thesis, Southborough University, UK.

\section{How to cite this article:}

Bhange, H.N., P.M. Ingle, B.K. Gavit and Singh, P.K. 2017. Urban Solid Waste Management for Sustainability: A Case Study. Int.J.Curr.Microbiol.App.Sci. 6(4): 523-529.

doi: https://doi.org/10.20546/ijcmas.2017.604.063 